\title{
The CurRency Composition of Sovereign DeBT ${ }^{\star}$
}

\author{
PABLO OTTONELLO \\ DIEGO J. PEREZ \\ University of Michigan \\ New York University
}

February 13, 2016

\begin{abstract}
The currency composition of sovereign external debt in emerging market economies is tilted towards foreign currency and the share of debt denominated in local currency is highly pro-cyclical. We study these facts through the lens of a quantitative model of optimal currencycomposition of sovereign debt when the government lacks commitment regarding monetary policy. High levels of debt in local currency give rise to incentives to dilute debt repayment through nominal currency depreciation. Governments tilt the currency-composition of debt towards foreign currency to avoid the inflationary costs associated with currency depreciation. This is done at the expense of foregoing the hedging properties of debt in local currency. The cyclicality of the currency-composition of sovereign debt responds to the cyclical properties of the benefits associated to debt dilution, which are higher in recessions. Inflation-linked bonds do not eliminate the time inconsistency problem of monetary policy.
\end{abstract}

Keywords: Sovereign debt, currency composition, monetary policy, time inconsistency.

* Ottonello (ottonellopablo@gmail.com): Department of Economics, University of Michigan. Perez (diego.perez@nyu.edu): Department of Economics, NYU. We thank Javier Bianchi, Alessandro Dovis, Andres Drenik, Jesse Schreger and the participants of the International Macro-Finance Conference at Chicago Booth for useful comments. Juan Martin Morelli provided excellent research assistance. 


\section{INTRODUCTION}

Governments issue debt that is denominated both in local and foreign currency. In recent years, the currency composition of sovereign debt has become an active margin of debt management. High levels of debt dollarization have often been associated with higher vulnerabilities to external crises. A sudden depreciation in the exchange rate can give rise to negative balance sheet effects for the debtor economy, and even precipitate a debt roll-over crisis. One way to avoid this vulnerability is to issue local-currency-denominated debt. However, the predominant view in policy circles until recently was that governments have difficulties in placing debt denominated in local currency. In fact, the inability of countries to borrow abroad in their own currency has been termed the 'original sin' (Eichengreen et al. (2002)).

In this paper we study the 'origins' of the so-called original sin. We propose a theoretical framework to jointly analyze the government's debt issuance choices by currency and the conduct of monetary policy, and argue that even if governments could issue debt in local currency, they would not be willing to do so to a great extent. A key reason for why governments tilt their debt portfolio towards foreign currency is that they want to avoid falling in the temptation of engaging in costly inflation. When governments face high levels of debt in local currency they may want dilute the value of their debt by generating nominal depreciation which entails inflationary costs. The shift in the currency composition of debt towards foreign currency debt comes at the expense of foregoing consumption insurance associated to borrowing in local currency. A quantitative analysis of the model for an average emerging market economy (EM) shows that this mechanism, together with the presence of quantitatively realistic costs of inflation can rationalize the observed average currency composition of sovereign external debt, as well as its cyclical properties.

The paper begins by documenting two stylized facts about the currency composition of sovereign debt in EMs. Using data for a panel of 18 countries we show that: (i) Debt currency composition tends to be tilted towards foreign currency: on average, around two thirds of sovereign external debt is denominated in foreign currency. (ii) The currency composition of debt has a strong cyclical component: in economic booms the share of debt denominated in local currency is higher than in recessions. The average correlation between output and the share of debt denominated in local currency is $40 \%$.

We then study these facts through the lens of the portfolio problem of a representative agent that faces income risk and can choose to save or borrow in securities denominated in foreign 
and local currency. This approach highlights the role of the hedging properties of both securities in determining optimal portfolio positions. Given that EMs tend to experience currency depreciation in recessions and appreciation during booms, debt in local currency constitutes a useful hedge against income risk. If the agent is indebted in local currency, when a negative income shock is realized, the exchange rate will likely depreciate which in turn lowers the value of debt repayments in local currency and attenuates the original income shock. The solution to this portfolio problem calls for issuing large levels of debt in local currency and little debt (if any) in foreign currency. This position is at odds with observed average levels of debt by currency in EMs.

We argue that this apparent disconnect is associated to the lack of commitment that the government has regarding its choice of monetary policy and its ability to dilute debt by engaging in inflation. To illustrate this we formulate a general equilibrium model in which the government chooses debt issuance in foreign and local currency as well as the aggregate rate of inflation in an endowment economy in which the exchange rate is determined endogenously. Inflation is costly, but also induces nominal exchange rate depreciation which in turn dilutes the value of debt in local currency. For higher levels of local-currency debt with which the government enters the period, the benefits associated to debt dilution are higher and therefore the optimal inflation is higher. This inflation is distortionary from an ex-ante point of view. With commitment the government does not engage in costly inflation since it internalizes that the benefits of debt dilution are offset by lower prices of debt in local currency in equilibrium. The government takes this into account when choosing debt in the previous period and tilts the currency composition of debt towards foreign currency denomination to avoid engaging in costly inflation in equilibrium. This shift in the currency composition of debt is done at the expense of further consumption insurance given that the model features an endogenous exchange rate that is counter-cyclical.

A calibrated version of the model which takes into account the welfare costs of inflation estimated from previous literature shows that the equilibrium currency-composition of sovereign debt predicted by the model is in line with that observed in the data. The model also correctly predicts the cyclical pattern of the currency composition of sovereign external debt observed in the data. The government optimally chooses to issue a larger share of debt in local currency in booms. This cyclical behavior is not linked to the hedging properties of debt in local currency over the cycle but rather to the cyclical properties of the benefits associated to debt dilution. In recessions the benefit of diluting debt via nominal depreciation induced by inflation is higher since saving resources for consumption is more valuable given that the marginal utility of 
consumption is higher in those states. This implies an optimal inflation rate that is countercyclical. The government internalizes this when choosing debt by currencies and chooses to reduce its debt issuance in local currency to avoid high levels of costly inflation in recessions.

It could be thought that one way to get around the possibility of diluting the value of debt in local currency via nominal inflation is to issuing inflation-linked debt. Yet, we argue that the issuance of inflation-linked bonds does not eradicate the time inconsistency problem. As long as monetary policy has an impact on economic activity and the real exchange rate, the government has an incentive to dilute the value of inflation-linked debt by inducing real exchange rate depreciation. We illustrate how the government can actually manipulate the real exchange rate with monetary policy by formulating a model of a production economy with nominal wage rigidities. In the context of that model, higher inflation can reduce the value of real wages, increase employment in the non-tradable sector and depreciate the real exchange rate. When the economy is with high levels of indexed debt in local currency, the government has an extra incentive to engage in inflation and increase inflation to induce real exchange rate depreciation and dilute the value of debt by a change in relative prices.

Related Literature. This paper builds upon the literature on sovereign debt and time inconsistency of monetary policy. It is also closely related to a number of recent papers that study the joint determination of sovereign debt issuance and inflation choices.

Following the original framework of sovereign defaultable debt developed in Eaton and Gersovitz (1981), a recent body of literature has studied the quantitative dynamics of sovereign debt. Arellano (2008) and Aguiar and Gopinath (2006) analyze sovereign debt and business cycle properties in emerging economies. Several studies have extended the framework to study different aspects related to debt management such as its maturity composition, its composition by residence of creditors, its liquidity management and post-default debt renegotiations. ${ }^{1}$ However, few papers focus attention on the currency-composition of sovereign debt. Bohn (1990) and Korinek (2009) study how debt denominated in different currencies can have different hedging properties for the borrower. The contribution of this paper is the analysis of a quantitative

\footnotetext{
${ }^{1}$ For example, Arellano and Ramanarayanan (2012) and Broner et al. (2013) study the optimal maturity composition of sovereign debt. Broner and Ventura (2011) and Perez (2015) analyze how the residence composition of government's creditors can shape the incentives to default. Bianchi et al. (2014) quantify the optimal stock of international reserves as a buffer for exogenous shutdowns of the market for sovereign debt. Yue (2010) and Pitchford and Wright (2012) introduce the dimension of post-default debt renegotiation into defaultable debt models. Aguiar and Amador (2014) survey recent advances in the field.
} 
model of currency composition of sovereign debt in a context in which the government can also choose its optimal monetary policy.

The paper is also builds the literature on the time inconsistency of government polices. Following the seminal contributions of Kydland and Prescott (1977) and Barro and Gordon (1983) a large strand of macroeconomic research has analyzed various contexts in which the ideal policies that a government would want to implement differ from the policies he can credibly promise. ${ }^{2}$ In those situations the government would like agents to trust his announcements but agents do not do so because they anticipate the government will have incentives to deviate from that announcement once they have taken their actions. In this paper the source of time inconsistency comes from the fact the government would like foreign investors and even himself to trust his desire of not to engage in distortionary inflation in the future but this is not possible as ex-post, once debt has been issued, the incentives to inflate arise to avoid paying to foreign investors.

Finally, the paper is also related to a set of papers that study the effects of partially defaulting on nominal debt by engaging in inflation, an idea that was explored in early work by Fischer (1983) and Calvo (1988). Aguiar et al. (2013) and Da-Rocha et al. (2013) analyze how the ability to dilute debt via inflation or devaluation can reduce the likelihood of suffering sellfullfiling debt crises. Araujo et al. (2013) estimate the welfare implications of issuing debt in domestic currency or in a common currency. Du and Schreger (2015) show that inflation can have associated negative effects on the balance-sheet of corporates. Sunder-Plassmann (2014) argues that inflation can help the government repay real debt in the long-run. Du et al. (2016) argue that various degrees of credibility regarding monetary policy can help reconcile crosssectional returns of nominal bonds. We contribute to this literature. First, we analyze how the incentives to inflate in equilibrium are affected when the government has the option to issue debt in multiple currencies. We argue that the incentives to engage in costly inflation makes the government tilt the composition of debt towards foreign currency denomination at the expense of consumption hedging rather than reduce the overall level of debt at the expense of consumption front-loading. Second, we present a quantitative dynamic model of sovereign debt that can reconcile the average and cyclical components of the currency-denomination of debt in emerging economies.

\footnotetext{
${ }^{2}$ Examples of applications of time inconsistency problems include capital taxation (Chari and Kehoe (1990)), monetary policy (Rogoff (1985), Chari et al. (2015)) and government default and bailouts (Chari and Kehoe (1993), Farhi and Tirole (2012)). A more general treatment of time inconsistency problems can be found in Phelan (2006).
} 
Layout. The remaining of the paper is organized as follows. Section 2 presents the data on currency composition of sovereign debt for a panel of EMs. Section 3 shows that the patterns in the data are at odds with the currency-denomination that comes out from an optimal portfolio problem. Section 4 presents the full model with endogenous choice of monetary policy, discusses the model calibration and assesses the model's success in explaining the data. Section 5 argues that the incentives to dilute debt through inflation remain even in the case of inflation-linked debt. Finally, section 6 concludes.

\section{Debt Currency-Composition in EMs: Stylized Facts}

This section documents the main patterns of the currency composition of sovereign debt observed in EMs. We are interested in studying how large are debt positions in domestic currency relative to foreign currency, and how the currency composition of debt fluctuates over the business cycle. To this end, we use data on sovereign external debt decomposed by currency of denomination and data on GDP for a panel of emerging economies. The source of the data on debt are Arslanalp and Tsuda (2014) which includes foreign holdings of both internationallyand domestically-issued government debt for the period 2003-2014 on a quarterly basis, and WDI which covers annual data on total external debt for a longer period of time. Data on quarterly real GDP comes from IFS and national sources. All countries included in the sample are middle income economies integrated to global capital market, as measured for example by the fact that at some point in time they were part of the set of countries included in J.P. Morgan's EMBI tracking sovereign debt in EMs.

Table 1 reports three key moments for a sample of EMs: total debt, the share of debt in local currency, and the correlation between the cyclical components of the share of debt in local currency and output. EMs display average levels of external public debt of the order of $22 \%$ of GDP. This average figures hide significant levels of heterogeneity and a downward trend over time in the last two decades (see Figure A.1).

Additionally, the currency composition of public debt is tilted towards debt in foreign currency. As shown in the second column, on average, less than one third of the public debt held abroad is denominated in local currency. Only 4 of our 18 countries have more than half of their external public debt denominated in local currency. The share of debt in local currency displayed a generalized upward trend in the last decade (see Figure A.2). Once this trend is removed, the share of public debt in local currency is on average procyclical, with booms characterized by larger positions of debt in local currency than busts. For the average country 
of our sample, the correlation between output and the detrended share of external public debt denominated in local currency. Again, only a few countries deviate from this pattern and show a countercyclical share in local currency. It could be thought that the strong procyclicality can be due exclusively to the episode of the global financial crisis. To address this issue we analyzed the episode of the Tequila crisis in Mexico which has historical data available. From the beginning to the end of 1994 the share of sovereign debt denominated in foreign currency increased from less than 5\% to more than 50\% (Figure A.3).

The main focus of the paper is placed on the analysis of the two stylized facts regarding the currency-composition of external sovereign debt, namely, an average currency composition of sovereign external debt that is tilted towards foreign currency and the procyclical behavior of the share of debt denominated in local currency.

\section{A Portfolio Problem Approach}

This section analyzes the consumption problem of a representative agent of an economy that faces income risk and can choose saving or borrowing in foreign and local currency. The agent is risk averse and his preferences are defined over an infinite stream of tradable and non-tradable consumption

$$
\mathbb{E}_{0}\left[\sum_{t=0}^{\infty} \beta^{t} u\left(c_{T, t}, c_{N, t}\right)\right]
$$

where $\beta \in(0,1)$ is the discount factor, $c_{T, t}$ is consumption of tradable goods in period $t, c_{N, t}$ is consumption of non-tradable goods in period $t$ and $u(\cdot)$ is increasing and concave. The agent has access to two securities for saving and borrowing purposes: debt in foreign and local currency. Debt in foreign currency is a one-period security that pays one unit of foreign currency in the following period. Similarly, debt in local currency is a security that pays one unit of local currency in the following period. Let $b_{t}^{*}, b_{t}$ be the stock of debt in foreign and local currency with which the agent enters the period and $y_{t}$ the total income of the agent measured in terms of tradable consumption. The budget constraint of the agent expressed in local currency is given by

$$
p_{T, t} c_{T, t}+p_{N, t} c_{N, t}=e_{t} y_{t}-e_{t} b_{t}^{*}-b_{t}+e_{t} q_{t}^{*} b_{t+1}^{*}+q_{t} b_{t+1}
$$

where $p_{T, t}, p_{N, t}$ is the price of tradables and non-tradables measured in local currency, $e_{t}$ is the exchange rate (i.e., the price of foreign currency in terms of local currency), $q_{t}^{*}$ is the price of debt in foreign debt measured in foreign currency and $q_{t}$ the price of debt in local currency measured in local currency. Assuming the law of one price holds for tradable goods 
TABLE 1. Facts on Sovereign External Debt by Currency

\begin{tabular}{lccc}
\hline \hline Country & $\begin{array}{c}\text { Total Debt } \\
\text { \% of GDP) }\end{array}$ & $\begin{array}{c}\text { Debt in LC } \\
\text { \% of Total Debt) }\end{array}$ & $\begin{array}{c}\text { Output-LC Debt } \\
\text { Correlation }\end{array}$ \\
\hline Argentina & $28 \%$ & $6 \%$ & $-2 \%$ \\
Brazil & $12 \%$ & $52 \%$ & $67 \%$ \\
Bulgaria & $34 \%$ & $0 \%$ & $54 \%$ \\
China & $7 \%$ & $11 \%$ & - \\
Egypt & $35 \%$ & $11 \%$ & - \\
Hungary & $37 \%$ & $31 \%$ & $47 \%$ \\
India & $15 \%$ & $11 \%$ & - \\
Indonesia & $31 \%$ & $18 \%$ & - \\
Lithuania & $21 \%$ & $3 \%$ & - \\
Malaysia & $23 \%$ & $66 \%$ & - \\
Mexico & $17 \%$ & $49 \%$ & $62 \%$ \\
Peru & $32 \%$ & $17 \%$ & $67 \%$ \\
Philippines & $36 \%$ & $13 \%$ & - \\
Poland & $22 \%$ & $38 \%$ & $27 \%$ \\
Russia & $3 \%$ & $18 \%$ & $30 \%$ \\
South Africa & $9 \%$ & $56 \%$ & - \\
Thailand & $13 \%$ & $68 \%$ & $-10 \%$ \\
Turkey & $20 \%$ & $31 \%$ & $55 \%$ \\
\hline Average & $22 \%$ & $28 \%$ & $40 \%$ \\
Standard Deviation & $11 \%$ & $22 \%$ & $28 \%$ \\
\hline \hline
\end{tabular}

Notes: Total refers to the ratio of total external public debt to annual GDP. Debt in LC refers to the share of external public debt denominated in local currency. Output-LC debt correlation refers to the correlation between the cyclical component of real GDP and the cyclical components the share of external public debt denominated in local currency. Both variables are detrended using the HP filter. Total debt is calculated as the country average for the period 1990-2014. The share of debt in local currency and the correlation with GDP is computed for the period 2004-2014, when data by currency becomes available.

and normalizing the international price of tradables to one we get that $p_{T, t}=e_{t}$ and can express 
the budget constraint in foreign currency

$$
c_{T, t}+p_{t} c_{N, t}=y_{t}-b_{t}^{*}-\frac{b_{t}}{e_{t}}+q_{t}^{*} b_{t+1}^{*}+\frac{q_{t}}{e_{t}} b_{t+1}
$$

where $p_{t} \equiv \frac{p_{N, t}}{e_{t}}$ is the real exchange rate (the relative price of non-tradables).

We assume securities are priced by risk-neutral foreign investors that have access to a risk-less security denominated in dollars that pays the international interest rate $R$. The price of both securities are then given by

$$
\begin{aligned}
q_{t}^{*} & =\frac{1}{R} \\
q_{t} & =\frac{1}{R} \mathbb{E}\left[\frac{e_{t}}{e_{t+1}}\right] .
\end{aligned}
$$

The set of stochastic exogenous processes for the agent is given by $\mathbf{s}_{t}=\left(y_{t}, e_{t}, p_{t}\right)$ which follows a Markov Process with transition probability function $f\left(\mathbf{s}_{t}, \mathbf{s}_{t+1}\right)$. We now define the agent's problem.

Definition 1 (Portfolio Problem). The agent's portfolio problem consists of choosing a sequence $\left\{c_{T, t}, c_{N, t}, b_{t+1}^{*}, b_{t+1}\right\}_{t=0}^{\infty}$ to maximize (1), subject to (2) - (4) and the law of motion of the exogenous stochastic processes.

This is a particular type of portfolio problem with incomplete markets and income risk that does not have closed form solutions. ${ }^{3}$ The optimal consumption process satisfies the following optimality conditions

$$
\begin{aligned}
\frac{u_{c_{T}}\left(c_{T, t}, c_{N, t}\right)}{u_{c_{N}}\left(c_{T, t}, c_{N, t}\right)} & =p_{t} \\
u_{c_{T}}\left(c_{T, t}, c_{N, t}\right) q_{t} & =\beta \mathbb{E}\left[u_{c_{T}}\left(c_{T, t+1}, c_{N, t+1}\right)\right] \\
\mathbb{C O V}\left[u_{c_{T}}\left(c_{T, t}, c_{N, t}\right), \frac{1}{e_{t}}\right] & =0 .
\end{aligned}
$$

Along the optimal consumption path, the marginal rate of substitution across tradable and non-tradable goods is equal to the real exchange rate (equation (5)). Additionally the optimal consumption process features the Euler equation for tradable goods (equation (6)). Equation (7) comes from the possibility of issuing debt in local currency which is a security that is priced by risk-neutral investors that care about the expected return in foreign currency. According to

\footnotetext{
${ }^{3}$ Duffie et al. (1997) characterize the solution to this class of problem in continuous time. Viceira (2001) provides an analytical characterization of an approximate solution to a problem.
} 
this equation, along the optimal consumption path the marginal utility of tradable consumption is isolated from any risk that stems from fluctuations in the exchange rate.

This consumption path is attained with certain positions in foreign and local currency that depend on the correlation between income and the inverse of the exchange rate. In order to further characterize the optimal debt positions for certain particular cases we make the following functional form assumptions

$$
u\left(c_{T, t}, c_{N, t}\right)=\frac{\left(c_{T, t}^{a} c_{N, t}^{1-a}\right)^{1-\sigma}}{1-\sigma} .
$$

Under this particular functional form the following proposition characterizes the optimal debt position in local currency.

Proposition 1. Assume the utility function takes the functional form (F1) and $y_{t}$ and $e_{t}^{-1}$ are i.i.d. over time. Define the standard deviation of random variable $X$ as $\sigma_{X}$ and correlation coefficient between $X$ and $Y$ as $\rho(X, Y)$.

(1) If $\rho\left(y_{t}, e_{t}^{-1}\right)=1$ then $b_{t}=\frac{\sigma_{y}}{\sigma_{e}-1}>0$ is part of the solution set of the portfolio problem.

(2) If $\rho\left(y_{t}, e_{t}^{-1}\right)=0$ then $b_{t}=0$ is part of the solution set of the portfolio problem.

(3) If $\rho\left(y_{t}, e_{t}^{-1}\right)=-1$ then $b_{t}=-\frac{\sigma_{y}}{\sigma_{e^{-1}}}<0$ is part of the solution set of the portfolio problem.

All proofs can be found in Appendix B.

This proposition illustrates the hedging properties of debt in local currency. When income is perfectly positively correlated with the inverse of the nominal exchange rate, the agent can attain perfect tradable consumption smoothing. It does so by issuing positive debt in local currency. This way, when there is a negative income shock the currency depreciates and the agent needs to repay less in terms of tradable consumption, muting this way the negative effect of the income shock. When income is perfectly negatively correlated with the inverse of the exchange rate the agent can also attain tradable consumption smoothing by saving in local currency. This way, when a negative income shock realizes the currency appreciates and the return on its savings measured in tradable consumption is higher. When income is uncorrelated with the exchange rate debt in local currency provides no hedging against income risk. In this case taking any position on local currency exposes the agent to an additional source of risk without perceiving any excess expected return for this since debt pricing is done by risk-neutral agents. 


\subsection{Quantitative Analysis}

In this subsection we calibrate the portfolio problem to that of a representative agent of the average economy studied in Section 2 and evaluate the quantitative results in the light of the data on debt by currency composition of sovereign external debt. We deliberately use a representative agent framework to shed light into data on sovereign debt to identify how the hedging properties of debt in different currencies would drive debt choices alone.

One period corresponds to one quarter. The instantaneous utility function is assumed to be given by (F1). The parameter values are summarized in Table 2. The international interest rate is set to $R=1.01$ and the risk aversion coefficient $\sigma$ is set to 2 , which are standard values in quantitative macro studies. For simplicity we set equal shares for tradables and non-tradables in the consumption aggregator. The discount factor is calibrated to target an average stock of external public debt of $31 \%$ of annual GDP. The calibrated value is $\beta=0.99$.

TABle 2. Model Calibration

\begin{tabular}{lcccc}
\hline \hline Parameter & & $\begin{array}{c}\text { Portfolio } \\
\text { Problem }\end{array}$ & $\begin{array}{c}\text { Full } \\
\text { Model }\end{array}$ & Source/Target \\
\hline Preferences & & & & \\
Risk aversion coefficient & $\sigma$ & 2.00 & 2.00 & \\
Tradable share in utility & $a$ & 0.50 & 0.50 & \\
Discount factor & $\beta$ & 0.99 & 0.99 & Avg. external debt (31\% of GDP) \\
Cost of inflation & $\phi$ & - & 20.0 & Burstein \& Hellwig (2008) \\
Endowments and Interest Rate & & & & \\
Risk free interest rate & $R$ & 1.01 & 1.01 & Share of tradable output (30\%) \\
Non-tradable endowment & $y_{N}$ & - & 2.62 & Tradable GDP \\
Autocorrelation of $y_{T}$ & $\rho_{y_{T}}$ & - & 0.54 & Tradable GDP \\
Std. dev. of $y_{T}$ & $\sigma_{y_{T}}$ & - & 0.03 & \\
\hline \hline
\end{tabular}

We reduce the dimensionality of the exogenous states by assuming that all variations in the real exchange rate comes from variations in the nominal exchange rate, or equivalently, $p_{t}=e_{t}^{-1}$. ${ }^{4}$ The exogenous state is thus given by $\mathbf{s}_{t}=\left(y_{t}, e_{t}^{-1}\right)$ which is assumed to follow a

\footnotetext{
${ }^{4}$ This assumption is consistent with a monetary policy of flexible exchange rate (which is the case for most of the countries analyzed in Section 2). In the model it the model takes form of targeting $p_{N, t}=1$.
} 
first-order VAR process in logs

$$
\log \mathbf{s}_{t}=\Phi_{0}+\Phi_{1} \log \mathbf{s}_{t-1}+\varepsilon_{t}
$$

where $\varepsilon_{t} \sim N(0, \Omega)$. This process is estimated with quarterly data on output and nominal exchange rate for the panel of countries analyzed in Section 2 for the 1990Q1-2014Q4 period. Output is measured as the cyclical component of real GDP measured in constant dollars. The inverse exchange rate is measured as the cyclical component of the inverse of nominal exchange rate vis-a-vis the US dollar. The estimation results are shown in Appendix ??. Both processes are estimated to be persistent. Additionally, output and the inverse of the nominal exchange rate are positively correlated as reflected by the positive covariance between their respective innovations. This positive correlation is consistence with the evidence shown in Section 2.

We analyze the model's quantitative performance by comparing moments from the model's ergodic set with moments of the data. To compute the model's moments we simulate the exogenous income and exchange rate processes for 10000 periods and trace the evolution of the debt positions. The moments are computed by eliminating the first 1000 observations. The moments from the data correspond to data on sovereign external debt for the same set of countries for the period 2004Q1-2014Q4 which is the sample for which the data is available.

Table 3 compares the moments regarding debt positions in the model with their data counterparts. In the data the average level of external public debt is $31 \%$ of GDP, of which $8 \%$ of GDP is denominated in local currency and the remaining $22 \%$ in foreign currency. In the model the average debt level matches its data counterpart since it is a target of the calibration. However, the split by currency denomination is $28 \%$ of GDP in local currency and only $2 \%$ in foreign currency. The high levels of debt in local currency are due to the strong negative correlation between output and exchange rate shown in the data. This co-movement makes debt in local currency an attractive security for smoothing tradable consumption.

The model cannot account either for the cyclicality of the currency composition of sovereign debt. While in the data the correlation between output and the difference between debt in local and foreign currency as a share of GDP is $66 \%$, its model counterpart is only $2 \%$. This suggests that the variation of the hedging properties of debt in local currency over the business cycle cannot account for the cyclical variation of the currency composition of debt.

The results of a portfolio problem reveal a simple puzzle, which we interpret as the presence of certain frictions that prevent governments from exploiting the hedging properties of debt in foreign and local currency. We explore the nature of these frictions in the next section. 
TABLE 3. Model Results

\begin{tabular}{lccc}
\hline \hline Moment & Data & $\begin{array}{c}\text { Portfolio } \\
\text { Problem }\end{array}$ & $\begin{array}{c}\text { Full } \\
\text { Model }\end{array}$ \\
\hline Average Levels & & & \\
Total Debt & 0.31 & 0.31 & 0.27 \\
Debt in LC & 0.09 & 0.28 & 0.03 \\
Debt in FC & 0.22 & 0.02 & 0.24 \\
Debt Currency Comp. & 0.28 & 0.92 & 0.12 \\
Cyclical Component & & & \\
Debt in LC - Output Correlation & 0.66 & 0.02 & 0.48 \\
\hline \hline
\end{tabular}

Notes: Debt currency composition is measured as the ratio between debt in local currency to total debt. The currency composition-output correlation refers to the correlation between the output and the ratio of the difference debt in local and foreign currency to GDP.

\section{Currency Composition with Time Consistent Monetary Policy}

\subsection{Model}

In this section we formulate a general equilibrium model of an economy in which the government can choose debt issuance and monetary policy without commitment. In this framework the nominal exchange rate is determined in equilibrium. Now the household's preferences are defined over an infinite stream of of tradable and non-tradable consumption and inflation

$$
\mathbb{E}_{0}\left[\sum_{t=0}^{\infty} \beta^{t} U\left(c_{T, t}, c_{N, t}, \pi_{t}\right)\right]
$$

and the period utility function is given by

$$
U\left(c_{T, t}, c_{N, t}, \pi_{t}\right)=\frac{\left(c_{T, t}^{a} c_{N, t}^{1-a}\right)^{1-\sigma}}{1-\sigma}-l\left(\pi_{t}\right)
$$

where $\pi_{t}$ is the gross inflation rate at period $t$ and $l(\cdot)$ is a convex function with $l^{\prime}(1)=0$. The disutility from inflation captures the distortionary costs associated to inflation. ${ }^{5}$ Households receive a stream of endowments of tradable goods $y_{T, t}$ and non-tradable goods $y_{N, t}$. We assume $y_{T, t}$ is stochastic and follows a Markov process with transition probability $g\left(y_{T, t}, y_{T, t+1}\right)$,

\footnotetext{
${ }^{5}$ In the context of a model of sovereign debt, Nuño and Thomas (2015) provide a micro-foundation for a quadratic specification for the reduced form costs of inflation based on Rotemberg-type of adjustment costs for prices.
} 
and $y_{N, t}=y_{N}$ is constant over time. Households also receive lump-sum transfers from the government.

The government is benevolent and cares about the utility of the representative household. It can issue debt in foreign and local currency (these securities are defined in the previous section) in international credit markets. These securities are bought by risk neutral foreign investors so its prices are given by (3) and (4). In addition, it determines its monetary policy by choosing the level of inflation without commitment.

We analyze the equilibrium in this economy by formulating the problem of a social planner. The planner chooses consumption allocations, debt allocations and inflation to maximize the agent's utility subject to the economy's resource constraint, equilibrium in markets and the link between monetary policy and relative prices. The equilibrium allocations can be decentralized by considering a competitive equilibrium in which households choose consumption allocations and the government chooses debt allocations and inflation.

We focus in the notion of a Markov Perfect Equilibrium in which policies depend on payoffrelevant states. Since the planner lacks commitment, it takes as given the optimal monetary policy of future planners. Let $\mathcal{E}\left(b^{*}, b, y_{T}, P_{-1}\right)$ be the perceived nominal exchange rate policy function of future planners. The planner's problem written in recursive form is given by

$$
V\left(b^{*}, b, y_{T}, P_{-1}\right)=\max _{b^{*}, b^{\prime}, \pi, e, c_{T}} U\left(c_{T}, y_{N}, \pi\right)+\beta \mathbb{E}\left[V\left(b^{* \prime}, b^{\prime}, y_{T}^{\prime}, P\right)\right]
$$

subject to

$$
\begin{aligned}
c_{T} & =y_{T}-b^{*}-\frac{b}{e}+\frac{b^{* \prime}}{R}+\frac{b^{\prime}}{R} \mathbb{E}\left[\frac{1}{\mathcal{E}\left(b^{*^{\prime}}, b^{\prime}, y_{T}^{\prime}, P\right)}\right] \\
P & =\pi P_{-1} \\
e & =a P\left(\frac{y_{N}}{c_{T}}\right)^{1-a}
\end{aligned}
$$

The first restriction corresponds to the resource constraint of the economy where the prices of both debts have been already replaced. Note that there is no non-tradable consumption in the resource constraint since market clearing for that good is already imposed. The second restriction defines inflation as the increase in the aggregate level of prices. The aggregate level of prices is in turn defined as the ideal price index that comes out from our preferences specification. The last restriction is the definition of the nominal exchange rate that is derived 
from the definition of the ideal price index and from the equilibrium relative price of nontradables. ${ }^{6}$

In Appendix $\mathrm{C}$ we show that we can reduce the dimensionality of the state in (P1) by scaling debt in local currency by the lagged level of aggregate prices. Given the recursive formulation of the planner's problem it is straightforward to define equilibrium.

Definition 2 (Markov Perfect Equilibrium). Define $\boldsymbol{s}=\left(b^{*}, b, y_{T}, P_{-1}\right)$ as the aggregate state. A Markov Perfect Equilibrium consists of a set of policy functions $\left\{c_{T}(\boldsymbol{s}), c_{N}(\boldsymbol{s}), b^{* \prime}(\boldsymbol{s}), b^{\prime}(\boldsymbol{s}), \pi(\boldsymbol{s})\right\}$, value function $V(\boldsymbol{s})$, perceived policies $\mathcal{E}(\boldsymbol{s})$ and prices $\left\{e(\boldsymbol{s}), q^{*}(\boldsymbol{s}), q(\boldsymbol{s})\right\}$ such that

- Policies $\left\{c_{T}(\boldsymbol{s}), e(\boldsymbol{s}), b^{* \prime}(\boldsymbol{s}), b^{\prime}(\boldsymbol{s}), \pi(\boldsymbol{s})\right\}$ solve the planner's problem (P1).

- Prices $\left\{q^{*}(s), q(s)\right\}$ solve (3), (4) and the market for non-tradable goods clear $c_{N}=y_{N}$

- Perceived policies coincide with actual policies: $\mathcal{E}(\boldsymbol{s})=e(\boldsymbol{s})$.

\subsection{Discussion of Main Trade-Offs}

In this model the nominal exchange is endogenously determined. Debt in local currency can help hedge income risk as long as the nominal exchange rate has variation over states. In particular, to the extent that the nominal exchange rate rate is negatively correlated with tradable income the government will find attractive to issue debt in local currency. In this model the equilibrium nominal exchange rate is counter-cyclical. According to the last restriction of (P1), the level of the exchange rate is proportional to the aggregate level of prices and to the relative price of non-tradables. The relative price of non-tradables is countercyclical in the model: given that markets are incomplete, tradable consumption co-varies positively with tradable endowment, which in turn delivers a counter-cyclical relative price of non-tradables. Additionally, as will be explained later, the optimal choice of inflation is also counter-cyclical. Therefore, in this model the counter-cyclicality of the nominal exchange rate comes from both the cyclicality of the real exchange rate and of the aggregate level of prices.

The trade-off involved in the choice of inflation can be seen from the problem (P1). On the one hand, higher inflation entails direct losses. On the other hand, higher inflation increases the level of prices, one of these being the nominal exchange rate. A nominal depreciation in turn dilutes $^{7}$ the value of repayment of debt in local currency and allows for higher consumption by

\footnotetext{
${ }^{6}$ Given our preferences, the ideal price index is given by $P_{t}=\left(\frac{e_{t}}{a}\right)^{a}\left(\frac{p_{N, t}}{1-a}\right)^{1-a}$. The equilibrium relative price of non-tradables (that come out of the household's first order condition) is $\frac{p_{N, t}}{e_{t}}=\frac{1-a}{a} \frac{c_{T, t}}{y_{N}}$. Combining these two equations we obtain the definition of the nominal exchange rate.

${ }^{7} \mathrm{By}$ dilute we mean to lower the value of debt expressed in terms of the representative basket of consumption.
} 
saving resources. ${ }^{8}$ The optimal inflation is static and depends on the outstanding level of debt in local currency. Figure 1, panel a depicts the qualitative behavior of optimal inflation as a function of debt in local currency for an uncalibrated version of the model. The optimal level of inflation is increasing in the level of debt denominated in local currency. For higher levels of debt in local currency the benefits of diluting the value of debt via inflation are higher, while the costs are independent of the level of debt. Additionally, for a given level of debt in local currency, optimal inflation is higher the lower are the direct welfare costs of inflation.

Figure 1. Main Trade-Offs in Debt and Inflation Choices

(A) Optimal Inflation $\pi(b, \cdot)$

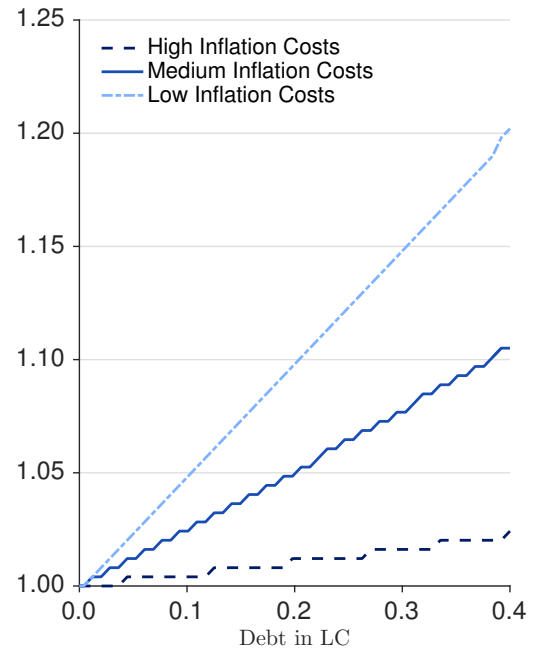

(B) Cont. Value $\mathbb{E} V(b, \cdot)$

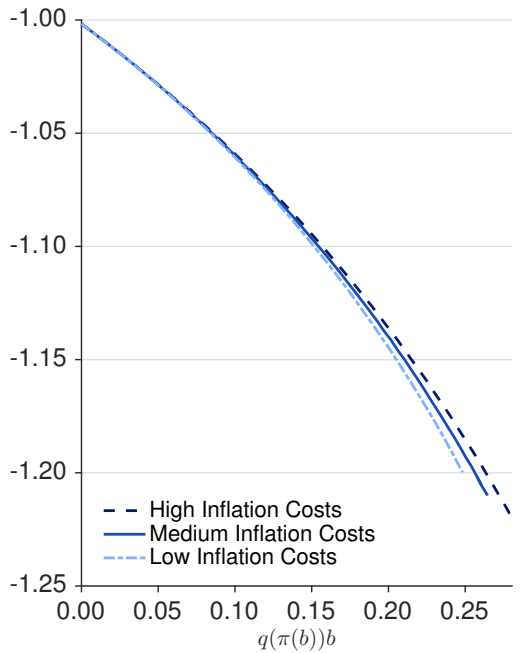

(c) Optimal Debt Allocations

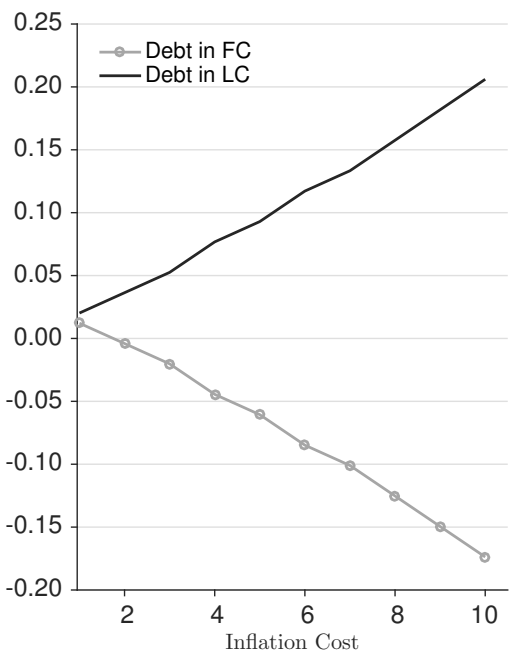

Notes: This graph illustrates the main trade-offs for an uncalibrated version of the model. The functional form of inflation costs is given by $l(\pi)=\frac{\psi}{2}(\pi-1)^{2}$. Panel a plots $\pi$ as a function of $b$, for different values of $\psi$, leaving constant the remaining states. Panel b plots $\mathbb{E}\left[V\left(\mathbf{s}^{\prime}\right)\right]$ as a function of $q\left(b^{\prime}, \cdot\right) b^{\prime}$. Panel c plots $b^{* \prime}, b^{\prime}$ as a function of $\psi$.

Inflation is distortionary from an ex-ante perspective. The reason is that in equilibrium foreign investors anticipate the optimal inflation choices and offer lower debt prices for higher levels of debt in local currency to compensate for the expected debt dilution. The lower debt prices offset the ex-post benefits of debt dilution. Therefore, from an ex-ante perspective inflation only entails the direct welfare costs. The government takes this into account when

\footnotetext{
${ }^{8}$ Additionally, by choosing inflation ex-post the government is able to make the payoffs of debt in local currency state-contingent. However, debt is a a security whose payoffs, measured in tradable consumption, are already state-contingent (even with zero inflation) since they depend on the real exchange rate. Therefore, there is no additional benefit from completing market with the choice of inflation.
} 
choosing the composition of debt. In particular, the government chooses a lower level of debt in local currency than what he would choose if he could commit not to inflate ex-post, precisely to avoid incurring in costly inflation in equilibrium. For higher inflation costs (which lead to higher inflationary discipline ex-post), debt in local currency is a more attractive security since the optimal ex-post inflation associated with that debt is lower. This is illustrated in panel b of Figure 1 that plots the expected continuation values as a function of resources raised with debt in local currency $\left(q b^{\prime}\right)$ for different inflation costs. For higher inflation costs the expected continuation value is higher for any given of resources raised with debt in local currency. This leads the government to choose higher levels of debt in local currency when inflation costs are higher.

Figure 1 panel c plots the optimal positions in both foreign and local currency as a function of inflation costs. As inflation costs decrease, and so does the inflationary discipline, the government reduces its debt position in local currency to indirectly discipline future governments from engaging in costly inflation and does this at the expense of lower consumption smoothing. Interestingly, the optimal government reaction to lower costs of inflation is also to reduce the assets in foreign currency in a way in which the net debt position is maintained and the intertemporal consumption path is not affected. This is an interesting result that is due to the joint analysis of debt in both currencies. The presence of inflation indiscipline ends up not creating a limit on total debt (and thus affecting inter-temporal consumption) but rather it creates an endogenous limit in debt currency composition which in turn affects the hedging properties of tradable consumption within a given period of time.

The model also has predictions regarding the cyclical behavior of the currency composition of sovereign debt. For a given level of debt in local currency the incentives to dilute debt via inflation differ with the realization of the endowment. In periods of low realizations of the endowment the marginal utility of consumption is high and so is the marginal benefit of saving resources for consumption by reducing debt repayments. This increases the attractiveness of diluting debt in local currency through inflation. This is illustrated in panel a of Figure 2 which depicts optimal inflation as a function of debt in local currency for different realizations of the tradable endowment. Given that the temptation to engage in costly inflation is higher in bad times the government optimally chooses its currency composition in such a way that the incentives to inflate in bad times are mitigated. If the tradable endowment process is persistent, the government reduces its issuance in local currency in low realizations of the tradable endowment. This way, the incentives to inflate -which are likely to be high given the 
persistence of the tradable endowment- are undermined by low levels of debt in local currency. The optimal choice of debt as a function of the tradable endowment is shown in panel b of Figure 2. The decrease in the level of debt in local currency is accompanied by a decrease in the level of assets in foreign currency in a way in which the overall level of debt is roughly unaffected.

Figure 2. The Cyclicality of the Currency Composition of Sovereign Debt

(A) Optimal Inflation

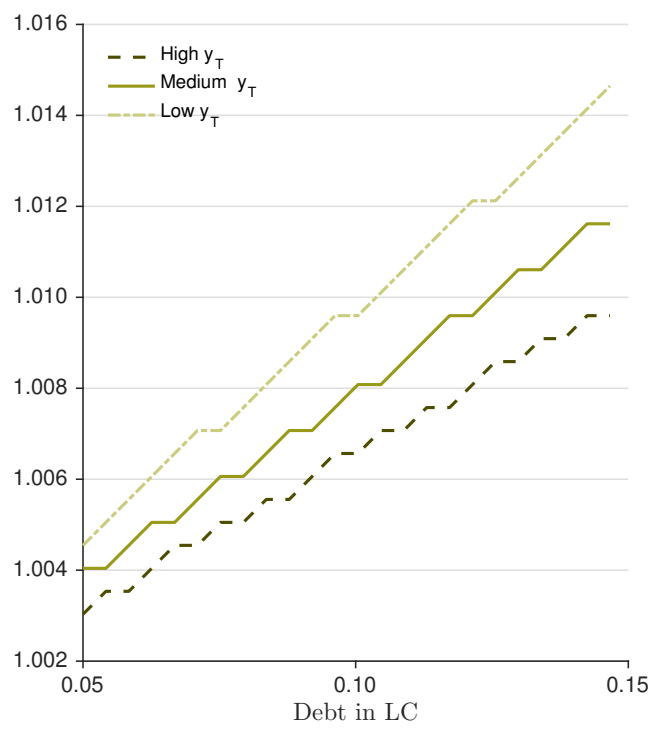

(B) Optimal Debt Allocations

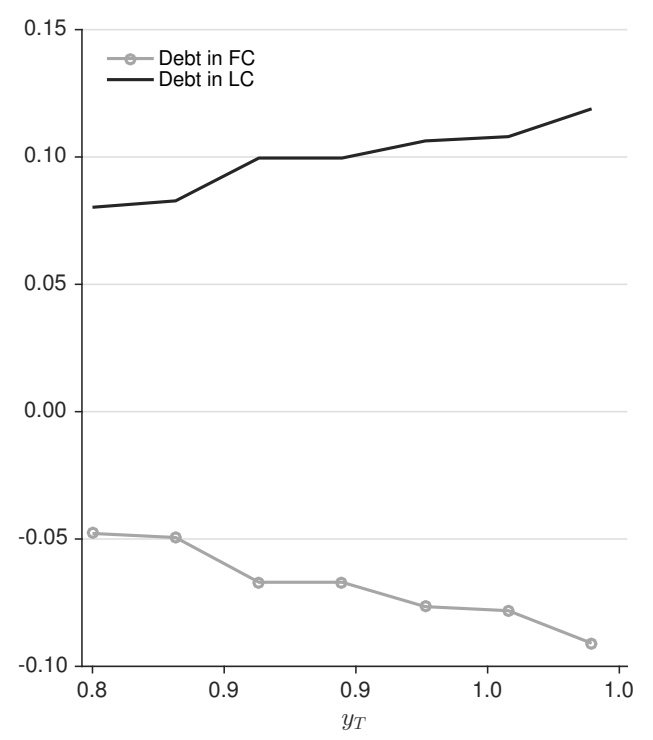

Notes: This graph illustrates the main trade-offs for an uncalibrated version of the model. The functional form of inflation costs is given by $l(\pi)=\frac{\psi}{2}(\pi-1)^{2}$. Panel a plots $\pi$ as a function of $b$, for different values of $y_{T}$, leaving constant the remaining states. Panel b plots $b^{* \prime}, b^{\prime}$ as a function of $y_{T}$.

Before assessing the quantitative properties of the model we characterize the equilibrium for the particular case in which there are no inflation costs. This is summarized in the following proposition.

Proposition 2 (Market Shutdown). If $l(\pi)=0$ for all $\pi$, the equilibrium features a market shutdown for debt in local currency: $q(\boldsymbol{s}) b^{\prime}(\boldsymbol{s})=0$.

The intuition behind this result is simple and relies on the lack of commitment. If the government does not have any cost of inflating debt, it will optimally choose to completely default on any positive debt in local currency by choosing an arbitrarily large level of inflation. Foreign investors anticipate this and are unwilling to lend in local currency (i.e. $q(\mathbf{s})=0$ ). Now we analyze the case of infinite costs of inflation. 


\subsection{Quantitative Analysis}

In this section we calibrate the full model to evaluate its quantitative properties. We maintain the calibration as close as possible to the calibration of the portfolio problem to be able to make comparisons across the two model specifications. One period corresponds to one quarter. We assume a quadratic loss function for inflation

$$
l(\pi)=\frac{\psi}{2}(\pi-1)^{2} .
$$

The parameters are shown in Table 2. The parameters associated to preferences and the international interest rate are kept at the same values as in the calibration of the portfolio problem. One new parameter that is introduced in this specification is the parameter $\psi$ associated to the disutility of inflation. We calibrate the value of $\psi$ to obtain a direct welfare cost of inflation that is in line with the cost estimated in Burstein and Hellwig (2008). In the main specification of that paper an increase in annual inflation of $10 \%$ (e.g. from $0 \%$ to $10 \%$ ) has associated a welfare loss equivalent to a drop in permanent consumption of $1.3 \%$. The value of $\psi$ that yield such welfare loss is 20. As argued in the previous section, the value of this parameter is important for the results since if governs the degree of time inconsistency of the government.

The exogenous state is the level of tradable endowment which we assume follow an $\mathrm{AR}(1)$ process in logs

$$
\log y_{T, t}=\rho_{y_{T}} \log y_{T, t-1}+\epsilon_{t}
$$

where $\epsilon_{t} \sim N\left(0, \sigma_{y_{T}}\right)$. This process is estimated with quarterly data on industrial production for the period 1990Q1-2014Q4 for the panel of countries analyzed in Section 2 that have available data. The data of industrial production was seasonally adjusted and detrended using the HP filter. The estimation results are shown in Table 2. The unconditional average level of $y_{T}$ is 1 and we set the level of the non-tradable endowment to $y_{N}=2.6$ to obtain a share of tradable output of $30 \%$ consistent with observed data for the countries in our sample.

We compute the same moments we analyzed in the portfolio problem specification which are shown in the last column of Table 3. The total level of public debt is roughly the same as in the data since it is a target of the calibration. The decomposition of debt by currency is much closer to the observed decomposition in the data. The level of debt in local currency is $3 \%$ of GDP and the level of debt in foreign currency is $24 \%$ compared to $8 \%$ and $22 \%$ in the data, respectively. This result suggests that the government's lack of commitment regarding monetary policy is quantitatively relevant in determining the optimal currency composition of 
government debt. What is particularly interesting is the fact that the presence of low welfare costs of inflation that are estimated from a separate literature can roughly reconcile the levels of debt in local and foreign currency.

The model also roughly matches the cyclicality of the currency composition of sovereign debt. While in the data the correlation between the cyclical component of output and the difference between debt in local and foreign currency is $66 \%$, the model counterpart is $48 \%$. Therefore the model proposes a quantitative explanation for the cyclical behavior of the currency composition of sovereign debt that is linked to the cyclical properties of the benefits associated to debt dilution by inflation rather than the cyclicality of the hedging properties of debt in local currency.

\section{The Case of Inflation-Linked Debt}

One way of issuing debt in domestic currency while overcoming the time inconsistency problem could be to issue debt denominated in local currency linked to inflation. This is in fact a security commonly observed that several countries including the US and EMs. We show that as long as monetary policy has a impact on economic activity the same time inconsistency problem is arises with inflation-linked debt.

\subsection{An Economy with Inflation-Linked Debt and Wage Rigidites}

We extend the model economy of Section 4 along two dimensions. First, we allow the government to save and borrow in a security whose payoff is linked to the change in the economy's price index. Second, we introduce production and nominal wage rigidities in the labor market (along the lines of Schmitt-Grohé and Uribe (forthcoming)). Production is conducted by competitive firms owned by households, using labor as input. The nominal wage rigidity gives rise to the possibility of involuntary unemployment, which depends on monetary policy. This setup allows us to study an environment in which monetary policy affects the real exchange rate, introducing a time inconsistency problem even under the presence of inflation-linked bonds.

Households. As in Section 4 households preferences are defined by (8) and (4.1). Each period, households receive a stochastic endowment $\left(y_{t}^{\mathrm{T}}\right)$, a lump-sum transfer from the proceedings of net borrowing from the government $\left(T_{t}\right)$, and profits from the ownership of firms producing nontradable goods $\left(\phi_{t}\right)$. They inelastically supply $\bar{h}$ hours of work to the labor market. Due to the presence of the wage rigidity (discussed in detail in the next subsections), households is

only able to sell $h_{t} \leq \bar{h}$ hours in the labor market. The actual hours worked $\left(h_{t}\right)$ is determined by firms and taken as given by the households. 
Households are assumed to be hand-to-mouth. ${ }^{9}$ The budget constraint of the agent expressed in local currency is given by:

$$
p_{T, t} c_{T, t}+p_{N, t} c_{N, t}=e_{t} y_{T, t}+T_{t}+w_{t} h_{t}+\phi_{t}
$$

where $w_{t}$ is the wage rate expressed in local currency.

The household's problem is then to choose state-contingent plans $\left\{c_{T, t}, c_{N, t}\right\}_{t=0}^{\infty}$ that maximize utility (8), subject to the sequence of budget constraints (10), the given sequence of prices and wages $\left\{p_{T, t}, p_{N, t}, w_{t}\right\}_{t=0}^{\infty}$, and the given sequence of government transfers, profits and hours worked $\left\{T_{t}, \phi_{t}, h_{t}\right\}_{t=0}^{\infty}$.

Firms. The representative firm has access to a technology to produce nontradable goods using labor as input described by $y_{N, t}=F\left(h_{t}\right)$, where $F: \mathbb{R}_{+} \rightarrow \mathbb{R}$ is a twice continuously differentiable, strictly increasing, strictly concave function. Profits each period are given by:

$$
\phi_{t}=p_{N, t} F\left(h_{t}\right)-w_{t} h_{t}
$$

The firms' problem is to choose $h_{t}$ to maximize profits given prices $p_{t}$ and $w_{t}$.

Government. As in Section 4, the government chooses inflation and sovereign external debt, making lump-sum transfers from the proceedings of net borrowing to households. In addition to securities denominated in foreign currency, the government is assumed to have access to an inflation-linked bond denominated in domestic currency. Inflation-linked debt in local currency is a security that pays for each unit of debt, one unit of local currency plus inflation in the following period. The budget constraint of the government expressed in local currency is given by:

$$
T_{t}=e_{t} q_{t}^{*} b_{t+1}^{*}+q_{t}^{\pi} b_{t+1}^{\pi}-e_{t} b_{t}^{*}-b_{t}^{\pi} \pi_{t}
$$

where $b_{t}^{\pi}$ denotes the stock of inflation-linked debt in local currency with which the agent enters period $t$.

Foreign Lenders. As in Section 4, we assume securities are priced by risk-neutral foreign investors that have access to a risk-less security denominated in foreign currency that pays the

\footnotetext{
${ }^{9}$ This assumption is made for simplicity as the focus of analysis if government rather than household debt. The government will indirectly make savings/consumption decisions for the households by issuing debt in multiple currencies.
} 
international interest rate $R$. The price of the security denominated in foreign currency is given by (3) and the price of the inflation-linked security is given by:

$$
q_{t}^{\pi}=\frac{1}{R} e_{t} \mathbb{E}\left[\frac{\pi_{t+1}}{e_{t+1}}\right] .
$$

Equilibrium. The market for nontradable goods clears at all times:

$$
c_{t}^{\mathrm{N}}=F\left(h_{t}\right)
$$

Combining condition (12) with the households' budget constraint, and the definition of the firms' profits, and the government's budget constraint, we obtain the resource constraint of the economy

$$
e_{t} c_{T, t}+e_{t} b_{t}^{*}+b_{t}^{\pi} \pi_{t}=e_{t} y_{T, t}+e_{t} q_{t}^{*} b_{t+1}^{*}+q_{t}^{\pi} b_{t+1}^{\pi} .
$$

Nominal wages are assumed to have a lower bound:

$$
w_{t} \geq \bar{w}
$$

which can be thought as a minimum wage.

Actual hours worked cannot exceed the inelastically supplied level of hours:

$$
h_{t} \leq \bar{h}
$$

When the nominal wage rigidity binds, the labor market can exhibit involuntary unemployment, given by $\bar{h}-h_{t}$. This implies a slackness condition must hold at all dates and states:

$$
\left(w_{t}-\bar{w}\right)\left(\bar{h}-h_{t}\right)=0 .
$$

This condition implies that when the nominal wage rigidity is not binding, the labor market must exhibit full employment, and if it exhibits unemployment, it must be the case that the nominal wage rigidity is binding.

Definition 3 (Competitive equilibrium). Given initial debt positions, $b_{0}^{*}$ and $b_{0}^{\pi}$, a statecontingent sequence of endowments, $\left\{y_{T, t}\right\}_{t=0}^{\infty}$, and government policies $\left\{\pi_{t}, b_{t+1}^{*}, b_{t+1}^{\pi}\right\}_{t=0}^{\infty}$ competitive equilibrium is a state-contingent sequence of allocations $\left\{c_{T, t}, c_{N, t}, h_{t}, T_{t}\right\}_{t=0}^{\infty}$ and prices $\left\{q_{t}^{*}, q_{t}^{\pi}, p_{N, t}, e_{t}, P_{t}\right\}_{t=0}^{\infty}$, such that:

(1) Allocations solve the household's and firms's problems at the equilibrium prices,

(2) Transfers satisfy the government budget constraint,

(3) Debt prices satisfy (3) and (11),

(4) Wages and employment satisfy conditions (14)-(16), 
(5) The market for non-tradable goods clears.

\subsection{Optimal Policy with Inflation-Linked Debt and Wage Rigidities}

We now consider the problem of a Ramsey planner who chooses debt and inflation without commitment to maximize household's utility subject to the implementability constraints that define the Competitive Equilibrium. As in Section 4 we focus in the Markov Perfect Equilibrium in which the planner takes as given the optimal monetary policy of future planners. Let $\mathcal{E}\left(b^{*}, b^{\pi}, y_{T}, P_{-1}\right)$ and $\Pi\left(b^{*}, b^{\pi}, y_{T}, P_{-1}\right)$ be the perceived nominal exchange rate policy function of future planners. The planner's problem written in recursive form is given by:

$$
\begin{aligned}
V\left(b^{*}, b^{\pi}, y_{T}, P_{-1}\right) & =\max _{b^{* \prime}, b^{\prime}, \pi, e, c_{T}, h} U\left(c_{T}, h, \pi\right)+\beta \mathbb{E}\left[V\left(b^{* \prime}, b^{\pi^{\prime}}, y_{T}^{\prime}, P\right)\right] \\
& \text { subject to } \\
c_{T} & =y_{T}-b^{*}-\frac{b^{\pi} \pi}{e}+\frac{b^{* \prime}}{R}+\frac{b^{\pi \prime}}{R} \mathbb{E}\left[\frac{\prod\left(b^{* \prime}, b^{\pi^{\prime}}, y_{T}^{\prime}, P\right)}{\left.\mathcal{E}\left(b^{*^{\prime}}, b^{\pi \prime}, y_{T}^{\prime}, P\right)\right]}\right. \\
P & =\pi P_{-1} \\
e & =a P\left(\frac{F(h)}{c_{T}}\right)^{1-a} \\
h & \geq \bar{h} \\
\bar{w} & \leq e\left(\frac{1-a}{a}\right)\left(\frac{c_{T}}{F(h)}\right)^{1-a} F^{\prime}(h)
\end{aligned}
$$

With respect to the planner problem laid out in as in Section 4, the planner in this economy has an additional control variable $(h)$ and two additional restrictions (the last two restrictions). The first of these new restriction establishes that the choice of employment cannot exceed the inelastically supplied level of hours. The second restriction imposes that the marginal product of labor measured in domestic currency cannot be less than the minimum wage.

The monetary policy trade-off of between inflation and unemployment in this economy can be characterized by the following condition:

REMARK 1. In an allocation which solves (P2) the following condition holds:

$$
\pi l^{\prime}(\pi)=\mu(1-a) P F^{\prime}(h)+\lambda \frac{b^{\pi} \pi}{e}
$$

where $\lambda$ is the Lagrange multiplier associated with the resource constraint (13), and $\mu$ is the Lagrange multiplier associated with the minimum wage constraint (the last restriction on P2). 
First, this condition indicates that in a state in which the stock of inflation-linked debt is zero $\left(b^{\pi}=0\right)$, the optimal allocation features a standard trade-off between inflation and output, in which the planner equates the marginal utility cost of inflation to the marginal benefit of relaxing the wage rigidity and increasing employment. Second, inheriting a positive level of borrowing in inflation-linked debt $\left(b^{\pi}>0\right)$, shifts this trade-off introducing an additional marginal benefit of inflation related to the marginal utility of consumption derived from diluting its debt position. Therefore, his choice is going to be more tilted towards inflation. This additional motive for inflation is only present when the government is able to manipulate the real exchange rate with inflation, which in the context of this model happens when the nominal wages hit their minimum level given rise to involuntary unemployment. The mechanism through which the government is able to reduce the real value of inflation-linked debt repayments is through a real exchange rate depreciation. Even though higher inflation cannot affect the value of inflationlinked debt, a real exchange rate depreciation can reduce its value measured in tradable goods, which are the goods on which the agents are ultimately trading.

In summary, this section presents a particular model in which the government is able to affect economic activity with monetary policy to illustrate how the incentives to dilute debt through inflation still persist even when debt is inflation-linked.

\section{Conclusion}

This paper focuses attention on two stylized facts regarding the currency denomination of sovereign external debt in emerging economies. First, the currency denomination of sovereign debt is tilted towards foreign currency. Second, the share of debt denominated in local currency is procyclical.

These facts cannot be rationalized by the hedging properties of both securities in determining optimal portfolio positions. Given that EMs tend to experience currency depreciation in recessions and appreciation during booms, debt in local currency constitutes a useful hedge against income risk so an optimal portfolio problem calls for issuing large levels of debt in local currency and little debt (if any) in foreign currency.

We show that what can help rationalize these positions is the presence of a time inconsistency problem that arises when issuing debt in local currency. Using a model of optimal choice of inflation denominated in foreign and local currency in which the government also controls monetary policy, we show that for higher levels of local-currency debt with which the government enters the period, the benefits associated debt dilution are higher and therefore the optimal 
inflation is higher. The government internalizes the presence of perverse incentives to engage in costly inflation ex-post and attenuates them by issuing more debt denominated in foreign currency and only little in domestic currency. This currency composition comes at the expense of foregoing the useful hedging properties of local-currency debt. We calibrate the model for a representative emerging economy and find that the model can account for the main two stylized facts highlighted at the beginning.

Finally, we also show that the incentives to dilute debt still persist even when the government can issue-inflation linked debt. In this case the dilution does not come through inflation but rather through real exchange rate depreciation. To the extent that the government can manipulate the real exchange rate with the conduct of monetary policy, higher levels of inflation-linked debt in domestic currency give rise to strong incentives to engage in costly inflation ex-post. 


\section{REFERENCES}

Aguiar, M. And M. Amador (2014): Sovereign Debt, North-Holland, 647-87.

Aguiar, M., M. Amador, E. Farhi, and G. Gopinath (2013): "Crisis and Commitment: Inflation Credibility and the Vulnerability to Sovereign Debt Crises," Manuscript, Harvard University.

Aguiar, M. And G. Gopinath (2006): "Defaultable Debt, Interest Rates and the Current Account," Journal of International Economics, 69, 64-83.

Araujo, A., M. LeOn, And R. Santos (2013): "Welfare analysis of currency regimes with defaultable debts," Journal of International Economics, 89, 143-153.

Arellano, C. (2008): "Default Risk and Income Fluctuations in Emerging Economies," The American Economic Review, 98, 690-712.

Arellano, C. And A. Ramanarayanan (2012): "Default and the Maturity Structure in Sovereign Bonds," Journal of Political Economy, 120, 187-232.

Arslanalp, S. And T. Tsuda (2014): "Tracking Global Demand for Emerging Market Sovereign Debt," IMF Working Paper 14/39.

Barro, R. J. And D. B. Gordon (1983): "Rules, discretion and reputation in a model of monetary policy," Journal of Monetary Economics, 12, 101-121.

Bianchi, J., J. C. Hatchondo, And L. Martinez (2014): "International Reserves and Roll-Over Risk," Manuscript, University of Wisconsin-Madison.

Bohn, H. (1990): "A positive theory of foreign currency debt," Journal of International Economics, 29, 273-292.

Broner, F. And J. Ventura (2011): "Globalization and Risk Sharing," The Review of Economic Studies, Vol. 78, No. 1.

Broner, F. A., G. Lorenzoni, And S. L. Schmukler (2013): "Why do emerging economies borrow short term?" Journal of the European Economic Association, 11, 67-100.

Burstein, A. And C. Hellwig (2008): "Welfare costs of inflation in a menu cost model," The American Economic Review, 438-443.

Calvo, G. A. (1988): "Servicing the public debt: The role of expectations," The American Economic Review, 647-661.

Chari, V. V., A. Dovis, And P. J. Kehoe (2015): "Rethinking Optimal Currency Areas," Manuscript, University of Minnesota.

Chari, V. V. And P. J. Kehoe (1990): "Sustainable plans," The Journal of Political Economy, 98, 783 . 
(1993): "Sustainable Plans and Debt," Journal of Economic Theory, 61, 230-261.

DA-Rocha, J.-M., E.-L. GimÉnez, AND F.-X. Lores (2013): "Self-fulfilling crises with default and devaluation," Economic Theory, 53, 499-535.

Du, W., C. Pflueger, And J. Schreger (2016): "Sovereign Debt Portfolios, Bond Risks, and the Credibility of Monetary Policy," Manuscript, Princeton University.

Du, W. And J. Schreger (2015): "Sovereign Risk, Currency Risk, and Corporate Balance Sheets," Manuscript, Harvard University.

Duffie, D., W. Fleming, And H. M. Soner (1997): "Hedging in incomplete markets with HARA utility," Journal of Economic Dynamics and Control, 21, 753-782.

Eaton, J. And M. Gersovitz (1981): "Debt with Potential Repudiation: Theoretical and Empirical Analysis," The Review of Economic Studies, 48, 289-309.

Eichengreen, B., R. Hausmann, And U. Panizza (2002): "Original sin: the pain, the mystery, and the road to redemption," In IADB Conference "Currency and Maturity Matchmaking: Redeeming Debt from Original Sin.' .

Farhi, E. And J. Tirole (2012): "Collective Moral Hazard, Maturity Mismatch, and Systemic Bailouts," The American Economic Review, 102, 60-93.

Fischer, S. (1983): "Welfare Aspects of Government Issue of Indexed Bonds," in Inflation, Debt, and Indexation, ed. by R. Dornbusch and M. H. Simonsen, M.I.T. Press, 247-266.

Korinek, A. (2009): "Insurance Properties of Local and Foreign Currency Bonds in Small Open Economies," Manuscript, Johns Hopkins University.

Kydland, F. E. And E. C. Prescott (1977): "Rules Rather than Discretion: The Inconsistency of Optimal Plans," Journal of Political Economy, 85, 473.

Nuño, G. And C. Thomas (2015): "Monetary Policy and Sovereign Debt Vulnerability," Manuscript, Banco de España.

Perez, D. J. (2015): "Sovereign Debt, Domestic Banks and the Provision of Public Liquidity," Manuscript, New York University.

Phelan, C. (2006): "Public trust and government betrayal," Journal of Economic Theory, $130,27-43$.

Pitchford, R. And M. L. J. Wright (2012): "Holdouts in Sovereign Debt Restructuring: A Theory of Negotiation in a Weak Contractual Environment," The Review of Economic Studies, 79, 812-837.

Rogoff, K. (1985): "The Optimal Degree of Commitment to an Intermediate Monetary Target," The Quarterly Journal of Economics, 100, 1169-1189. 
Schmitt-Grohé, S. And M. Uribe (forthcoming): "Downward Nominal Wage Rigidity, Currency Pegs, and Involuntary Unemployment," Journal of Political Economy.

Sunder-Plassmann, L. (2014): "Inflation, Default and the Denomination of Sovereign Debt," Manuscript, University of Minnesota.

Viceira, L. M. (2001): "Optimal Portfolio Choice for Long-Horizon Investors with Nontradable Labor Income," The Journal of Finance, 56, 433-470.

Yue, V. Z. (2010): "Sovereign Default and Debt Renegotiation," Journal of International Economics, 80, 176-187. 


\section{Appendix A. Additional Figures}

Figure A.1. Evolution of Total External Public Debt

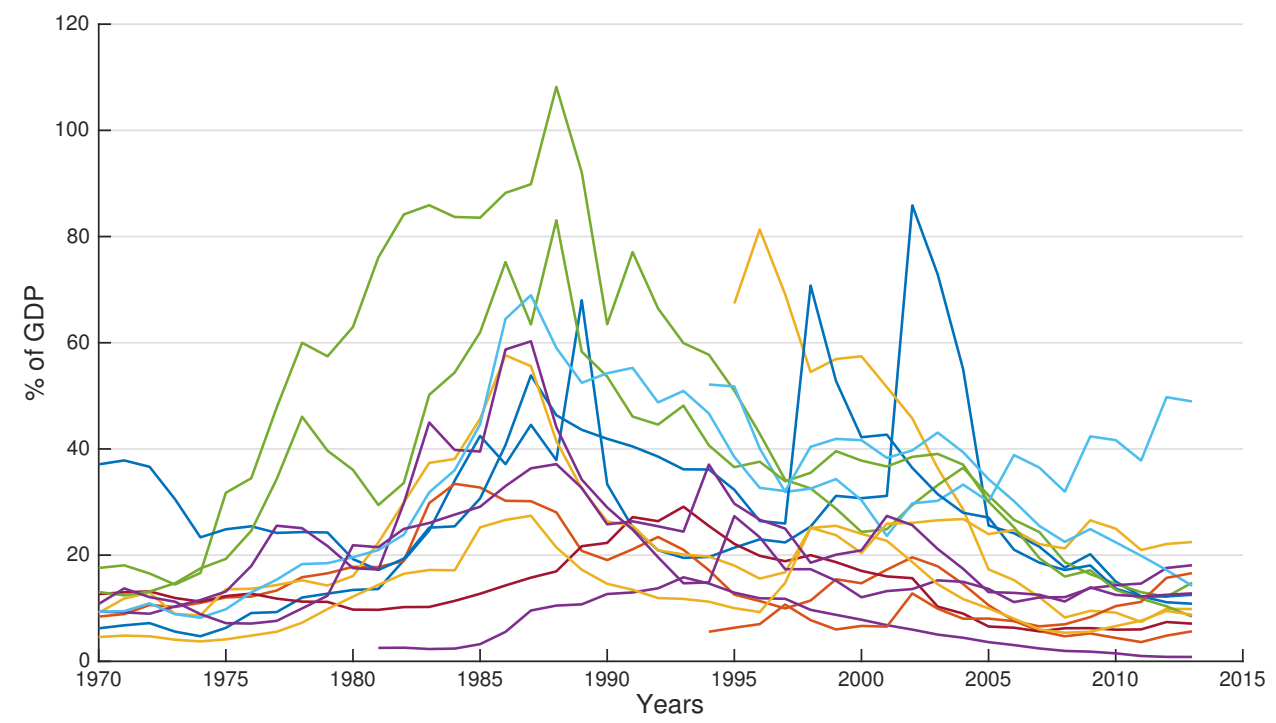

Notes: Based on WDI data. Stock of external public debt as a percentage of annual GDP for the countries in the sample.

Figure A.2. Evolution of the Currency Composition of Sovereign External Debt

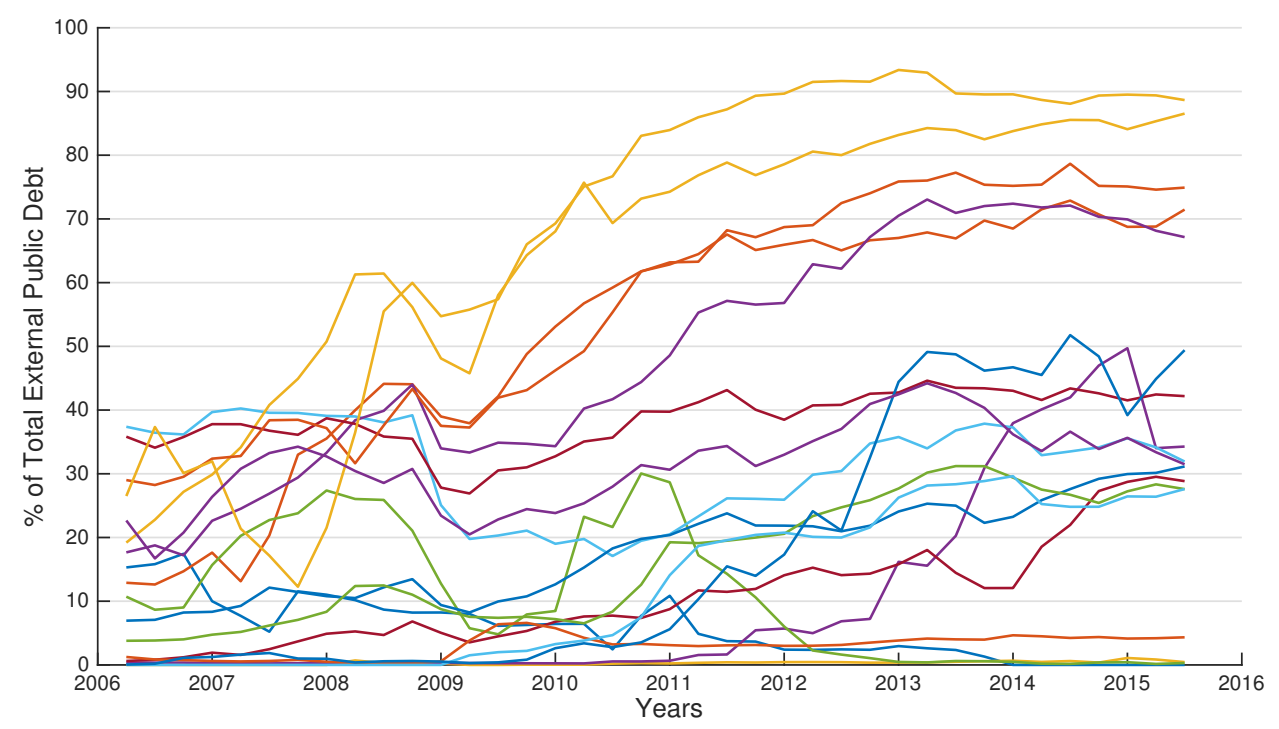

Notes: Based on Arslanalp \& Tsuda (2014). Share of sovereign external debt in local currency as a fraction of total sovereign external debt for the countries in the sample. 
Figure A.3. Currency Composition of Sovereign Debt: The Case of Mexico During the Tequila Crisis

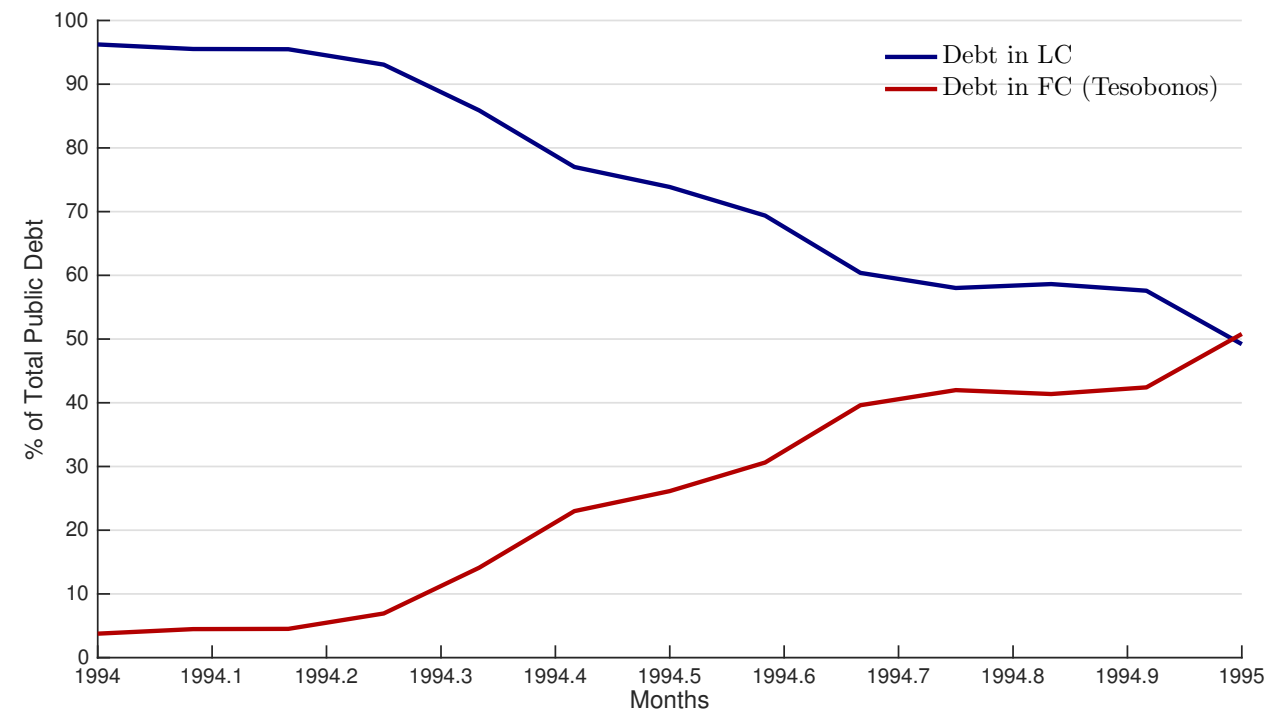

Notes: Based on data from Banxico. Domestic currency debt includes Ajustabonos, CETES and Bondes. Foreign-currency-denominated debt includes Tesobonos.

\section{Appendix B. Omitted Proofs and Results}

\section{Proof of Proposition 1}

Define the aggregate exogenous state as $\mathbf{s}_{t}=\left(y_{t}, e_{t}^{-1}, p_{t}\right)$. The portfolio problem can be expressed recursively as

$$
\begin{aligned}
& V\left(b^{*}, b, \mathbf{s}\right)=\max _{b^{* \prime}, b^{\prime}, c_{T}, c_{N}} u\left(c_{T}, c_{N}\right)+\beta \mathbb{E}\left[V\left(b^{* \prime}, b^{\prime}, \mathbf{s}^{\prime}\right) \mid \mathbf{s}\right] \\
& \text { s.t. } \\
& c_{T}+p c_{N}=y-b^{*}-e^{-1} b+q^{*} b^{* \prime}+e^{-1} q b^{\prime} \\
& b^{*}+e^{-1} b \leq \bar{b} \\
& \operatorname{Pr}\left(\mathbf{s}^{\prime} \mid \mathbf{s}\right)=\Gamma\left(\mathbf{s}^{\prime}, \mathbf{s}\right)
\end{aligned}
$$

The second restriction implies a borrowing constraint on total debt which prevents Ponzi games.

We assume $\bar{b}$ is large enough such that this constraint is not binding and thus we can ignore 
this constraint. ${ }^{10}$ The optimality conditions that are necessary and sufficient are given by

$$
\begin{aligned}
\frac{u_{c_{T}}\left(c_{T}, c_{N}\right)}{u_{c_{N}}\left(c_{T}, c_{N}\right)} & =p \\
u_{c_{T}}\left(c_{T}, c_{N}\right) q & =\beta \mathbb{E}\left[u_{c_{T}}\left(c_{T}^{\prime}, c_{N}^{\prime}\right)\right] \\
u_{c_{T}}\left(c_{T}, c_{N}\right) e^{-1} q & =\beta \mathbb{E}\left[u_{c_{T}}\left(c_{T}^{\prime}, c_{N}^{\prime}\right) e^{-1^{\prime}}\right]
\end{aligned}
$$

Now we derive equation (7) from (20), (21) and the definition of debt prices. From the definition of covariance we have

$$
\mathbb{E}\left[u_{c_{T}}\left(c_{T}^{\prime}, c_{N}^{\prime}\right) e^{-1^{\prime}}\right]=\mathbb{C O V}\left(u_{c_{T}}\left(c_{T}^{\prime}, c_{N}^{\prime}\right), e^{-1^{\prime}}\right)+\mathbb{E}\left[u_{c_{T}}\left(c_{T}^{\prime}, c_{N}^{\prime}\right)\right] \mathbb{E}\left[e^{-1^{\prime}}\right]
$$

Using (21) and (4) we get

$$
u_{c_{T}}\left(c_{T}, c_{N}\right) \mathbb{E}\left[e^{-1^{\prime}}\right]=\beta R\left[\mathbb{C O V}\left(u_{c_{T}}\left(c_{T}^{\prime}, c_{N}^{\prime}\right), e^{-1^{\prime}}\right)+\mathbb{E}\left[u_{c_{T}}\left(c_{T}^{\prime}, c_{N}^{\prime}\right)\right] \mathbb{E}\left[e^{-1^{\prime}}\right]\right] .
$$

Using (20) this last equation is equivalent to

$$
\mathbb{C} \mathbb{O V}\left(u_{c_{T}}\left(c_{T, t}, c_{N, t}\right), e^{-1}\right)=0
$$

To prove the proposition we assume that the optimal controls $b^{* \prime}, c_{T}, c_{N}$ satisfy (18)-(20) and we find $b^{\prime}$ that satisfies (22). In what follows we make use of the functional form assumption (F1).

Consider the case in which $\rho\left(y, e^{-1}\right)=1$. Then there exist $\gamma_{0}, \gamma_{1}>0$ such that $e^{-1}=\gamma_{0}+\gamma_{1} y$, with $\gamma_{1}=\left(\operatorname{var}\left(e^{-1}\right) / \operatorname{var}(y)\right)^{1 / 2}$. Substituting this equation into (18) and using (19) we get

$$
c_{T}\left[1+\frac{1-a}{a}\right]=y-b^{*}-\left(\gamma_{0}+\gamma_{1} y\right) b+q^{*} b^{* \prime}+q^{*} \mathbb{E}\left[\gamma_{0}+\gamma_{1} y^{\prime} \mid y\right] b^{\prime}
$$

Note that the conditional expectation does not depend on $y$ due to the iid assumption. From (23) we can see that by setting $b^{\prime}=\left[\left(1-q^{*} \rho_{y}\right) \gamma_{1}\right]^{-1}>0$ we make $c_{T}$ independent of the realization of $y$ which implies that (22) is satisfied given that under our functional form assumptions the marginal utility of tradable consumption as function of tradable consumption only.

The proof for the case of $\rho\left(y, e^{-1}\right)=-1$ is analogous with the difference that now we can write $e^{-1}=\gamma_{0}-\gamma_{1} y$, for some $\gamma_{0}$ and $\gamma_{1}=\left(\operatorname{var}\left(e^{-1}\right) / \operatorname{var}(y)\right)^{1 / 2}$.

Now consider the case of $\rho\left(y, e^{-1}\right)=0$. We show that for $b=0$ (22) is satisfied. Using (18), (19) and (4) we have that

$$
c_{T}\left[1+\frac{1-a}{a}\right]=y-b^{*}-e^{-1} b+q^{*} b^{* \prime}+q^{*} \mathbb{E}\left[e^{-1^{\prime}}\right] b^{\prime}
$$

\footnotetext{
${ }^{10} \mathrm{We}$ also implicitly assume the exchange rate process is bounded above.
} 
Since $e^{-1}$ is iid over time then $c_{T}$ is independent of $e^{-1}$ if $b=0$, which implies that (22) is satisfied.

\section{Proof of Proposition 2}

First note that the $\pi^{*}(\mathbf{s})=\infty$ for any $\mathbf{s}$ with $b>0$. Since in equilibrium foreign lenders must obtain an expected return of $R$, then in equilibrium it must be the case that $q(\mathbf{s})=0$ whenever $b^{\prime}(\mathbf{s})>0$. For states in which $b^{\prime}(\mathbf{s})=0$ then the result follows trivially.

\section{Appendix C. Numerical Solution}

Provided that there is positive inflation in equilibrium, the price level and the nominal level of debt denominated in local currency will exhibit a trend. We deal with this property by reducing the dimensionality of the state space of the recursive problem to three variables that are stationary. Define $\tilde{b}=\frac{b}{a P_{-1} y_{N}^{1-a}}$, this ratio corresponds to the level of local-currency debt scaled by the lagged aggregate level of prices and other scalars. Then the problem (P1), can be re-expressed as

$$
V\left(b^{*}, \tilde{b}, y_{T}\right)=\max _{b^{* \prime}, \tilde{b}^{\prime}, \pi, c_{T}} U\left(c_{T}, y_{N}, \pi\right)+\beta \mathbb{E}\left[V\left(b^{* \prime}, \tilde{b}^{\prime}, y_{T}^{\prime}\right)\right]
$$

subject to

$$
c_{T}=y_{T}-b^{*}-\tilde{b} \frac{c_{T}^{1 / 2}}{\pi}+\frac{b^{* \prime}}{R}+\frac{\tilde{b}^{\prime}}{R} \mathbb{E}\left[\mathcal{X}\left(b^{* \prime}, b^{\prime}, y_{T}^{\prime}, P\right)\right]
$$

where $\mathcal{X}\left(b^{* \prime}, b^{\prime}, y_{T}^{\prime}, P\right)$ is the perceived ratio of the square root of future tradable consumption to future inflation. In equilibrium, this should be a fixed point, i.e., $\mathcal{X}\left(b^{* \prime}, b^{\prime}, y_{T}^{\prime}, P\right)=\frac{c_{T}^{1 / 2}}{\pi}$. We solve for equilibrium using global numerical method based on value function iteration. We first conjecture a guess for $\mathcal{X}$, iterate the value function until convergence, then update our initial guess of $\mathcal{X}$ and follow the same procedure until convergence. 